\title{
ANALISIS STRATEGI PEMUNGUTAN PAJAK BUMI DAN BANGUNAN TERHADAP EFEKTIFITAS TARGET PENERIMAAN PBB (STUDI KASUS NAGARI TIMBULUN KAB. SIJUNJUNG)
}

\author{
Yulistia \\ Dosen Universitas Ekasakti \\ Jalan Veteran Dalam No.26 Padang \\ Email: Yulistia.adrian@outlook.co.id
}

\begin{abstract}
According to Law No. 28 of 2009 the Rural and Urban Land and Building Tax (PBB P2) is one of the taxes managed by local governments. Nagari Timbulun which is in the Sijunjung Regency region has a fairly large tax arrears. The amount of tax arrears is a challenge for the Nagari Timbulun government in optimizing revenue. This study describes the constraints experienced by the Nagari Timbulun government in implementing UN revenues. This study explains the strategies used, and also knows the level of effectiveness of $P B B$ revenue as a local tax. This research is a descriptive study with interview and documentation data collection techniques. The selection of informants uses a purposive technique. The technical analysis of the data used is qualitative and quantitative. The results of this study indicate that the Nagari Timbulun Government is experiencing problems due to the low level of public education, poverty, community distrust and inadequate service. This can also be seen from the UN reception Nagari Timbulun with a range of 60-80 ratio classified as less effective.
\end{abstract}

Keywords: PBB, Regional Tax, Strategy, Effectiveness

\begin{abstract}
Abstrak: Menurut Undang-Undang No 28 taun 2009 Pajak Bumi dan BangunanPedesaan dan Perkotaan (PBB P2) merupakan salah satu pajak yang dikelola olehpemerintah daerah. Nagari Timbulun yang berada di wilayah Kabupaten Sijunjung memiliki tunggakan pajak yang cukup besar. Besarnya tunggakan pajak menjadi tantangan bagi pemerintahan Nagari Timbulun dalam mengoptimalkan penerimaan. Penelitian ini mendeskripsikanmengenai kendala yang dialami oleh pemerintahan Nagari Timbulun dalam penerapan penerimaan PBB. Penelitian ini menjelaskan mengenai strategi yang digunakan, serta mengetahui tingkat efektivitaspenerimaan PBB sebagai pajak daerah. Penelitian ini merupakan penelitian deskriptif dengan teknik pengumpulan data berupawawancara dan dokumentasi. Pemilihan informan menggunakan teknik purposive. Teknis analisis data yang digunakan adalah kualitatif dan kuantitatif. Hasil penelitian ini menunjukkan Pemerintahan Nagari Timbulun mengalami kendala yang disebabkan tingkat pendidikan masyarakat yang masih rendah, kemiskinan, ketidakpercayaan masyarakat dan kurang optimal dalam pelayanan. Hal ini juga dapat dilihat dari penerimaan PBB Nagari Timbulun dengan range ratio 60-80 tergolong kurang efektif.
\end{abstract}

Kata Kunci: PBB, Pajak Daerah, Strategi, Efektivitas 


\section{Pendahuluan}

Sumber terbesar pendapatan suatu negaraberasal dari pajak yang sangat penting bagi pelaksanaan dan peningkatan pembangunan nasional bertujuan untuk mencapai kemakmuran dan kesejahteraan masyarakat. Salah satu pajak yang menjadi potensi sumber pendapatan negaraadalah Pajak Bumi dan Bangunan (PBB) yaitu iuran yang dikenakan terhadap orang atau badan secara nyata yang mempunyai hak, memiliki, menguasai dan memperoleh manfaat dari bumi dan bangunan (Rahman,2011). Sejak tahun 2011 penarikan Pajak Bumi dan Bangunan (PBB) dilimpahkan ke Pemerintah Kota sesuai dengan Peraturan Bersama Menteri Keuangan dan Menteri Dalam Negeri nomor: 213/PMK.07/2010, nomor: 58 tahun 2010 tentang Tahapan Persiapan Pengalihan Pajak Bumi dan Bangunan Perdesaan dan Perkotaan sebagai Pajak Daerah. Dengan pengalihan ini makaproses kegiatan yang berhubungan dengan Pajak Bumi dan Bangunan Pedesaan danPerkotaan (PBB-P2) akan diselenggarakan oleh Pemerintah Daerah (Kabupaten/Kota).Tujuan Pengalihan pengelolaan Pajak Bumi dan Bangunan Pedesaan dan Perkotaan (PBB-P2) adalah "untuk memberikan kewenangan yang lebih besar dalam perpajakan dengan memperluas basis pajak daerah dan penetapan tarif pajak" (www.pajak.go.id:2014).

Hartono (2012) dalam penelitiannya yang berjudul Evaluasi Pelaksanaan Pengalihan Pajak Bumi Dan Bangunan Perdesaan Dan Perkotaan (PBB-P2) Sebagai Salah Satu Sumber Pendapataan Asli Daerah Kabupaten Sukoharjo hasil penelitiannya menyatakan bahwa pengalihan Pajak Bumi dan Bangunan menjadi pajak daerah berpengaruh postif terhadap Pendapatan Asli Daerah. Semakin tinggi pencapaian penerimaan PBB, maka Pendapatan Asli Daerah juga akan meningkat. Selanjutnya penelitian lain yang dilakukan oleh Adelina (2013) mengemukakan bahwapenerimaan Pajak Bumi dan Bangunan telah melampaui target yang ditetapkan oleh Pemerintah Kota Gresik. Dari hasil kedua penelitian diatas menunjukkan pencapaian yang positif terhadap penerimaan PBB, namun tidakmencerminkan bahwa hasil dari penerimaan PBB tersebut sama dengan daerah lain, hal ini dikarenakan potensi dari setiap wilayah berbeda-beda.

Berdasarkan data yang diperolehdimana Nagati Timbulun dengan luas daerah .250 ha dan jumlah penduduk 3.229 orang terbagi atas 4 (empat) jorong yaitu Balai-Balai, Tandikek, Koto Timbulun dan Sibisir. Selain data diatas diperoleh data target penerimaan dan realisasi PBB dari tahun 2014-2018 dimanaselama 5 tahun terakhir realisasi penerimaan PBB tidak sesuai dengan target penerimaan PBB yang diharapkan. Dari data tersebut dilihat adanya setiap tahun tunggakan pajak di Nagari Timbulun. Tunggakan yang terjadi tentu akan berpengaruh terhadap efektivitas penerimaan Pajak Bumi dan Bangunan. Hal ini disebabkan minimnya pengetahuan masyarakat tentang perpajakan, kesadaran masyarakat untuk menjadi Wajib Pajak yang bijak, tidak adanya sosialisasi tentang perpajakan, tidak adanya koordinasi antara pihak Kecamatan/Kelurahan ke Nagari yang mengakibatkan semakin meningkatnya penunggakan pembayaran pajak oleh wajib pajak. Pemerintah Nagari Timbulun tentu mempunyai strategi yang dapatb digunakan untuk mengoptimalkan penerimaan PBB. Dari potensi penerimaan Pajak Bumi dan Bangunan yang ada pada Nagari Timbulun, diharapkan strategi yang tepat untuk mengoptimalkan penerimaan Pajak Bumi dan Bangunan. Dari strategi tersebut juga bisa melihat apakah ada pengaruhnya terhadap efektivitas penerimaan PBB yang telah ditentukan sebelumnya.

\section{Landasan Teori \\ Pajak}

Menurut Mardiasmo (2009), pajak adalah iuran rakyat kepada kas Negara berdasarkan UndangUndang (yang dapat dipaksakan) dengan tidak mendapat jasa timbal (kontraprestasi) yang langsung dapat ditunjukkan dan yang digunakan untuk membayar pengeluaran umum. 


\section{Sistim Pemungutan Pajak}

Sistem pemungutan pajak dapat dibagi menjadi berikut ini: (a) official assessment system, sistem ini merupakan sistem pemungutan pajak yang memberi wewenang kepada pemerintah (fiskus) untuk menentukan besarnya pajak yang terutang; (b) self assessment system, sistem ini merupakan pemungutan pajak yang memberi wewenang, kepercayaan, tanggung jawab kepada Wajib Pajak untuk menghitung, memperhitungkan, membayar, dan melaporkan sendiri besarnya pajak yang harus dibayar; (c) withholding system, sistem ini merupakan sistem pemungutan pajak yang memberi wewenang kepada pihak ketiga untuk memotong atau memungut besarnya pajak yang terutang oleh Wajib Pajak.

\section{Hambatan Pemungutan Pajak}

Hambatan terhadap pemungutan pajak yang dikemukakan oleh Mardiasmo (2011) dapat dikelompokkan menjadi: (a) perlawanan pasif, dan (b) perlawanan aktif. Perlawanan aktif meliputi semua usaha dan perbuatan yang secara langsung ditujukan kepada fiskus dengan tujuan untuk menghindari pajak. Bentuknya antara lain: (1) tax avoidance, usaha meringankan beban pajak dengan tidak melanggar undang-undang; (2) tax evasion, usaha meringankan beban pajak, dengan cara melanggar undang-undang (menggelapkan pajak). Sedangkan menurut Nin Yasmine Lisasih (2011) dalam artikel all about law mengemukakan kendala dalam pemungutan pajak secara umum baik pajak pusat maupun pajak daerah, seringkali terdapat kendala yang melemahkan dalam pemungutan pajak. Kendala-kendala tersebut antara lain: (1) berbagai peraturan pelaksanaan undang-undang yang sering kali tidak konsisten dengan undang-undangnya, apabila peraturan pelaksanaan yang dijadikan dasar dalam melaksanakan aturan hukum pajak tidak konsisten dengan undang-undang tentu akan mengakibatkan kendala yang fatal dalam pemungutan pajak.; (2) kurangnya pembinaan antara pajak daerah dengan pajak nasional, pembinaan pajak daerah harus dilakukan secara terpadu dengan pajak nasional. Pembinaan harus dilakukan secara terus menerus terutama mengenai objek dantarif pajaknya supaya antara pajak pusat dan pajak daerah saling melengkapi; (3) database yang masih jauh dari standar internasional, database sangat menentukan untuk menguji kebenaran pembayaran pajak dengan sistem self-assasment. Persepsi masyarakat, bahwa banyak dana yang dikumpulkan oleh pemerintah digunakan secara boros atau korup, juga menimbulkan kendala untuk meningkatkan kepatuhan wajib pajak; (4) lemahnya penegakan hukum (law enforcement) terhadap kepatuhan membayar pajak bagi penyelenggara negara, Law enforcement merupakan pelaksanaan hukum oleh penjabat yang berwenang dibidang hukum pelaksanaan hukum dilingkungan birokrasi khususnya badan pemerintahan di bidang perpajakan dalam melakukan pemeriksaan terhadap penyelenggara nergara ternyata belum ada gebrakannya. Seharusnya bila dilakukan tentu membantu dalam mewujudkan good governance dalam bentuk pemerintah yang bersih; (5) kurangnya atau tidak adanya kesadaran masyarakat, pemungutan pajak dituntut kesadaran warga negara untuk memenuhi kewajiban kenegaraan. Kurangnya atau tidak adanya kesadaran masyarakat sebagai wajib pajak untuk membayar pajak ke negara mengakibatkan timbulnya perlawanan atau terhadap pajak merupakan kendala dalam pemungutan pajak sehingga mengakibatkan berkurangnya penerimaan kas negara.

\section{Pajak Daerah}

Menurut dasar hukum pemungutan pajak daerah adalah Undang-Undang Nomor 28 tahun 2009 tentang pajak daerah dan retribusi daerah "Pajak daerah adalah kontribusi wajib kepada Daerah yang terutang oleh orang pribadi atau badan yang bersifat memaksa berdasarkan Undang-Undang dengan tidak mendapatkan imbalan secara langsung dan digunakan untuk keperluan daerah bagi sebesar-besarnya kemakmuran rakyat." 


\section{Pajak Bumi Dan Bangunan}

Menurut Mardiasmo (2011) bumi adalah permukaan dan tubuh bumi yang ada dibawahnya. Permukaan bumi meliputi tanah dan perairan pedalaman (termasuk rawa-rawa, tambak, perairan) serta laut wilayah republik Indonesia. Bangunan adalah kontruksi tekhnik yang ditanam atau dilekatkan secara tetap pada tanah dan atau perairan. Menurut Rahman (2011) PBB merupakan jenis pajak yang sepenuhnya diatur oleh pemerintah dalam menentukan besar pajaknya (menganut sistem pemungutan official assessment system). Pajak ini bersifat kebendaan dalam arti besarnya pajak terutang ditentukan oleh keadaan objek yaitu bumi/tanah dan atau bangunan. Di sini keadaan subjek (siapa yang membayar) tidak ikut menetukan besarnya pajak.

\section{Subjek Pajak Bumi dan Bungunan}

Menurut Waluyo (2011) subjek pajak dalam pajak bumi dan bangunan perdesaan dan perkotaan adalah orang pribadi atau badan yang secara nyata mempunyai suatu hak atas Bumi dan/atau memperoleh manfaat atas Bumi, dan/atau memiliki, menguasai, dan/atau memperoleh manfaat atas bangunan. Sedangkan yang menjadi Wajib Pajak Bumi dan Bangunan dan Perdesaan dan Perkotaan adalah orang pribadi atau badan yang secara nyata mempunyai suatu hak atas bumi dan/atau memperoleh manfaat atas bumi, dan/atau memiliki, menguasai, dan/atau memperoleh manfaat atas bangunan. Menurut Mardiasmo (2011) Subjek pajak adalah orang atau badan yang secara nyata mempunyai suatu hak atas bumi dan atau memperoleh atas bangunan. Dengan demikian tanda pembayaran/ pelunasan pajak bukan merupakan bukti pemilikan hak: (1) Subjek pajak yang dikenakan kewajiban membayar pajak menjadi wajib pajak; (2) Dalam hal atas suatu objek pajak belum jelas diketahui wajib pajaknya, Direktur Jendral Pajak dapat menetapkan subjek pajak sebagai wajib pajak; (3) Subjek pajak yang ditetapkan oleh Dirjen Pajak dapat memberikan keterangan secara tertulis kepada Direktur Jendral Pajak bahwa ia bukan wajib pajak terhadap objek pajak yang dimaksud; (4) Bila keterangan yang diajukan oleh wajib pajak kepada Dirjen Pajak disetujui, maka Dirjen Pajak membatalkan penetapan sebagai wajib pajak dalam jangka waktu satu bulan sejak diterimanya surat keterangan dimaksud; (5) Bila keterangan yang diajukan itu tidak disetujui, maka Direktur Jendral Pajak mengeluarkan surat keputusan penolakan dengan disertai alasan-alasannya; (6) Apabila setelah jangka waktu satu bulan sejak tanggal terimanya keterangan, Dirjen Pajak tidak memberikan keputusan, maka keterangan yang diajukan itu dianggap disetujui.

\section{Objek Pajak dan Objek Tidak Kena Pajak PBB}

Objek pajak adalah Bumi dan Bangunan Perdesaan dan perkotaan adalah Bumi dan/ Bangunan yang dimiliki, dikuasai, dan/ digunakan untuk kegiatan usaha perkebunan, perhutanan dan pertambangan. Objek pajak yang tidak dikenakan PBB Perdesaan dan Perkotaan adalah objek pajak yang menurut (Undang-undang nomor 28 tahun 2009 Pasal 77), sebagai berikut: (1) digunakan oleh Pemerintah dan Daerah untuk penyelenggaraan pemerintah;(2) digunakan semata-mata untuk melayani kepentingan umum di bidang ibadah, sosial, kesehatan, pendidikan dan kebudayaan nasionala yang tidak dimaksudkan untuk memperoleh keuntungan; (3) digunakan untuk kuburan, peninggalan purbakala, atau yang sejenis dengan itu; (4) merupakan hutang lindung, hutan suaka alam, hutan wisata, taman nasional, tanah penggembalaan yang dikuasai oleh desa, dan tanah negara yang belum dibebani suatu hak; (5) digunakan oleh perwakilan diplomatic dan konsulat berdasarkan asas perlakuan timbal balik; dan (6) digunakan oleh badan atau perwakilan lembaga internasional yang di tetapkan dengan Peraturan Menteri Keuangan.

\section{Strategi Pemungutan PBB}

Menurut Wikipedia (dalam artikel id.wikipedia.org/Strategi:2013) strategi adalah pendekatan secara 
keseluruhan yang berkaitan dengan pelaksanaan gagasan, perencanaan, dan eksekusi sebuah aktivitas dalam kurun waktu tertentu. Di dalam strategi yang baik terdapat koordinasi tim kerja, memiliki tema, mengidentifikasi faktor pendukung yang sesuai dengan prinsip-prinsip pelaksanaa gagasan secara rasional, efisien dalam pendanaan, dan memiliki taktik untuk mencapai tujuan secara efektif. Menurut Fuad (dalam artikel Payment online system PBB:(2012) selaku kepala Direktorat Jendral Pajak, software /aplikasi sistem informasi PBB terdiri dari beberapa bagian/modul. Salah satunya adalah pembayaran. Selama ini strategi pembayaran atau pemungutan yang di terapkan oleh Dirjen pajak adalah melalui kerjasama dengan pemerintah lokal atau kota atau kabupaten. Dengan jumlah objek PBB yang relative banyak dan berdomisili dimanapun sehingga sangat penting adanya system pembayaran online dan semi online yang handal untuk mengelola. Aplikasi/software sistem informasi pembayaran PBB dapat menghandle beberapa cara pembayaran PBB, yaitu: (1) online bank seperti ATM dan bank yang ditunjuk oleh departemen pajak melalui aplikasi online teller (core banking app) yang memiliki sistem Host to Host dengan sistem Dirjen Pajak. Tanda bayar melalui medai ini akan mendapat tanda setor (hasil dari printer thermal dan print dari teller); (2) aplikasi Payment Online System PBB yang ada di KPP Pratama tanda bayar melalui media ini akan mendapat Surat Tanda Terima Setoran (STTS); (3) aplikasi mobil keliling PBB adalah aplikasi pembayaran PBB yang dijalankan oleh petugas Dinas Pendapatan secara berpindah-pindah (mobling) dari satu wilayah satu ke wilayah (kelurahan) lainnya. Tanda bayar melalui media ini akan mendapat Surat Tanda Terima Setoran(STTS).

\section{Pengukuran Kinerja dan Peningkatan Kinerja}

Menurut Mahsun (2006) pengukuran kinerja bukanlah tujuan terakhir melainkan merupakan alat agar dihasilkan manajemen yang lebih efisien dan terjadi peningkatan kinerja. Hasil dari pengukuran kinerja akan memberitahu kita apa yang telah terjadi, bukan mengapa hal itu terjadi atau apa yang harus dilakukan. Suatu organisasi harusmenggunakan pengukuran kinerja secara selektif agar dapat mengidentifikasi strategi dan perubahan operasional yang dibutuhkan serta proses yang diperlukan dalam perubahan tersebut. Pengukuran kinerja menyediakan dasar bagi organisasi untuk menilai: (1) bagaimana kemajuan atas sasaran yang telah ditetapkan; (b) membantu dalam mengenali area-area kekuatan dan kelemahan; (c) menentukan tindakan yang tepat untuk meningkatkan kinerja; (d) menunjukan bagaimana kegiatan mendukung tujuan organisasi; (e) membantu dalam membuat keputusan-keputusan dengan langkah inisiatif; (f) mengutamakan alokasi sumber daya; (g) meningkat produk-produk dan jasa-jasa kepada pelanggan.

\section{Metodologi Penelitian}

\section{Jenis Penelitian}

Jenis penelitian ini menggunakan metode analisa deskriptif. dimana dalam penelitian ini akan menjelaskan mengenai kendala yang dialami oleh Pemerintah Nagari Timbulun dalam pemungutan PBB serta strategi yang digunakan dalam pemungutan PBB.

\section{Teknik Pengumpulan Data}

Meode pengumpulan data dalam penelitian ini adalah: (1). Studi lapangan adalah mengumpulkan data dengan cara mengadakan wawancara secara langsung dengan Wali Nagari Timbulun, (2). Studi pustaka adalah memperoleh data dari informasi seperti buku literature, internet dan data lainnya berupa data primer dan data sekunder. Selain cara diatas data penelitian ini diperoleh melalui observasi, dokumentasi dan wawancara.

\section{Populasi dan Sampel}

Populasi dari penelitian ini masyarakat Nagari Timbulun yang merupakan wajib pajak PBB. 
Sedangkan sampel dipilih secara purposive, ditunjuk berdasarkan sejauh mana masyarakat tersebut memahami tentang Pajak Bumi dan Bangunan, kredibilitas, kekayaan informasi yang mereka miliki,dan apakah sesuai dengan masalah pada penelitian ini.

\section{Teknik Analisa Data}

Teknik analisis data penelitian dilakukan secara analisa kualitatif dan kualitatif. Teknis analisis data kualitatifdigunakan untuk menjawab rumusan masalah yang datanya berupa pernyataan yang tidak berupa angka-angka, yang kemudian disusun secara naratif dengan polaatau susunan tertentu. Teknik analisis data ini digunakan untuk menjawab permasalahan mengenai kendala serta realisasi strategi dalam penerimaan Pajak Bumi dan Bangunan Pemerintah Nagari Timbulun. Teknis analisis kuantitatif digunakan untuk mengetahui efektivitas penerimaan Pajak Bumi dan Bangunan setelah ditetapkansebagai pajak daerah. Analisis tersebut menggunakan rasio efektivitas keuangan daerah sesuai dengan Keputusan Mendagri.

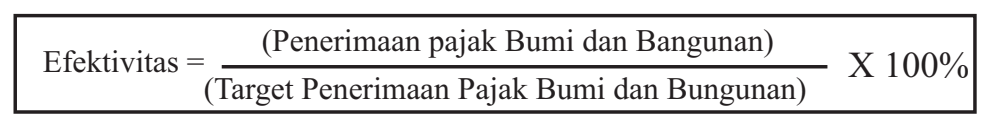

\section{Analisis dan Pembahasan \\ Efektivitas Penerimaan Pajak Bumi dan Bangunan}

Berikut data penelitian target penerimaan dan realisasi Pajak Bumi dan Bangunan (PBB) tahun 2014-2018 Nagari Timbulun

Tabel 4.1

Target dan Realisasi Penerimaan PBB

Tahun 20142018

\begin{tabular}{cccccc}
\hline No & Tahun & Target & Realisasi & $\begin{array}{c}\text { Tingkat } \\
\text { Efektifitas }\end{array}$ \\
\hline $\mathbf{1}$ & 2014 & 8.908 .729 & 5.536 .500 & $62,14 \%$ & Kurang efektif \\
$\mathbf{2}$ & 2015 & 8.838 .464 & 6.628 .848 & $65 \%$ & Kurang efektif \\
$\mathbf{3}$ & 2016 & 8.855 .769 & 6.287 .596 & $71 \%$ & Kurang efektif \\
$\mathbf{4}$ & 2017 & $10,778.200$ & 8.083 .650 & $75 \%$ & Kurang efektif \\
$\mathbf{5}$ & 2018 & 12.919 .260 & 10.206 .215 & $79 \%$ & Kurang efektif \\
\hline
\end{tabular}

Sumber: Kantor Wali Nagari Timbulun

Dari tabel 4.1 data diatas menunjukan bahwa realisasi pencapaian target penerimaan PBB setiap tahun ada mengalami kenaikan,namun belum menacapai sesuai dengan target yang diharapkan. Dapat dilihat pada tahun anggaran 2014 dan 2015 realisasi PBB berada pada presentase $62,14 \%$ dan $65 \%$ mengalami kenaikan hanya sebesar 2,86\%, dimana pada tahun 2014 dengan target Rp.8.908.729dan realisasi Rp.5.536.500, sedangkan tahun 2015 dengan target sebesar Rp.8.838.464 dan realisasi sebesar Rp.6.628.848. Sedangkan pada tahun anggaran 2016 sampai 2017 berada pada presentase $71 \%$ dan $75 \%$ mengalami peningkatan lebih yaitu 4\%. Pada tahun 2016 dengan target Rp.8.855.769 dan realisasi Rp.6.287.596 mendapat presentase 71\%, sedangkan pada tahun 2017 dengan target sebesar Rp.10.778.200dan realisasi Rp 8.083.650 dengan presentase 75\%. Untuk 
tahun 2018 dengan target Rp.12.919.260 dengan realisasi sebesar Rp. 10.206.215 dengan persentase $79 \%$. Dari data tabel 4.1 di atas dapat dilihat bahwa penerimanaan Pajak Bumi dan Bangunan di Nagari Timbulun setiap tahun berada pada rasio 60-80 dimana rangenya dinyatakan dengan kurang efektif. Hal ini dapat dilihat meskipun adanya peningkatan persentase penerimaan PBB setiap tahun tetapi masih berada pada rasio kurang efektif. Berdasarkan hasil wawancara yang dilakukan kepada Wali Nagari Timbulun, tidak tercapainya penerimaan PBB disebabkan beberapa faktor yang mempengaruhi sebagai berikut:

1. Tingkat pendidikan masyarakat yang rendah.

Rendahnya pendidikan masyarakat Nagari Timbulun yang sebagian besar lulusan sekolah menengah pertama kebawah, membuat masyarakat tidak menyadari pentingnya manfaat membayar pajak. Selain itu, faktor tidak adanya sosialisasi dari petugas Nagari Timbulun membuat ketidaktahuan masyarakat tidak berubah sama sekali.

2. Kemiskinan

Kemiskinan adalah faktor yang paling berpengaruh terhadap pencapaian target realisasi penerimaan pajak bumi bangunan Nagari Timbulun. Masyarakat yang memiliki tunggakan pajak bumi bangunan, karena dilandasi faktor kemiskinan menjadi enggan untuk membayar pajak bumi bangunan. Dengan faktor ini petugas wali nagari Timbulun tidak bisa memaksakan masyarakat tersebut agar membayar pajak bumi bangunan.

3. Ketidakpercayaan

Ketidakpercayaan masyarakat kepada pengelolaan pajak disebabkan banyaknya berita mengenai penyalahgunaan dana pajak oleh oknum yang tidak bertanggung jawab. Penyalahgunaan tersebut sampai kepada masyarakat menengah kebawah Nagari Timbulun, membuat masyarakat menjadi enggan dalam membayar pajak. Karena sebahagian besar masyarakat menengah kebawah Nagari Timbulun memiliki tingkat pendidikan dibawah sekolah menengah pertama yang kurang dapat mencerna dengan baik berita yang ditayangkan di televisi nasional.

4. Pelayanan yang kurang baik

Setelah ada niat dari masyarakat untuk membayar pajak, faktor yang krusial lainnya adalah pelayanan dari petugas penerimaan pajak itu sendiri. Dengan kurang baiknya pelayanan yang diberikan oleh pegawai wali nagari Timbulun membuat masyarakat menjadi malas untuk membayar pajak. Peningkatan pelayanan pegawai wali nagari Timbulun akan membuat minat masyarakat dalam membayar pajak menjadi naik.

Berdasarkan faktor diatasWali Nagari Timbulun melakukan pembenahan agar penerimaan Pajak Bumi dan Bangunan (PBB) dapat bertambah setiap tahunnya, cara pembenahan itu diantaranya yaitu dengan memperjelas data dari objek pajak terutama kejelasan status kepemilikan objek pajak, melakukan perbaikan data Wajib Pajak dan tetap menggunakan sistem 'Jemput Bola' yaitu dimana petugas pajak yang diberi tugas untuk menagih atau memungut Pajak Bumi dan Bangunan (PBB) dengan mendatangi secara langsung tempat tinggal Wajib Pajak.

\section{Simpulan dan Saran simpulan}

Berdasarkan dari penelitian ini dapat disimpulkan bahwa strategi pemungutan Pajak Bumi dan Bangunan (PBB) yang dilaksanakan Pemerintah Nagari Timbulun belum sesuai untuk realisasi target penerimaan Pajak Bumi dan Bangunan (PBB). Secara keseluruhan strategi yang dilakukan oleh Pemerintah Nagari Timbulun sudah cukup baik untuk diterapkan. Dilihat dari data yang diperoleh jumlah penerimaan Pajak Bumi dan Bangunan (PBB) semakin meningkat jumlahnya, tetapi untuk persentase pencapaian target masih kurang efektif dari tahun ke tahun. 


\section{Saran}

Selaku Pemerintah yang berwenang dalam pemungutan Pajak Bumi dan Bangunan (PBB) sebagai Pajak Daerah sebaiknya Pemerintahan Nagari Timbulun melakukan pembenahan yang lebih baik lagi dalam melakukan pemungutan maupun penagihan Pajak Bumi dan Bangunan (PBB). Menganalisis dari data yang diperoleh bahwa Pemerintah Nagari Timbulun sebaiknya melakukan pendekatan pelayanan dengan cara penyuluhan Pajak Bumi dan Bangunan (PBB), mengadakan pertemuan dengan masyarakat tentang pentingnya membayar pajak, mengadakan Lokakarya yaitu berkumpul dengan para ahli Pajak untuk memecahkan masalah tersebut, serta mengadakan diskusi denganmasyarakat sebagai Wajib Pajak agar Pemerintah Nagari Timbulun juga mengetahui yang menjadi keinginan dan pendapat warganya. Sesungguhnya ini semua kembali pada kesadaran warga sebagai Wajib Pajak untuk membayar Pajak Bumi dan Bangunan (PBB).

\section{Daftar Pustaka}

Adelina, Rima. 2013. Analisis Efektivitas danKontribusi Penerimaan Pajak Bumi danBangunan (PBB) TerhadapPendapatam Daerah di Kabupaten Gresik. Jurnal Akuntansi UNESA. Vol 1, No 2

Direktorat Jendral Pajak. 2010. Media keuangan. http://www.kemenkeu.go.id/Diakses pada tanggal 5 Mei 2014.

. 2012. Pengalihan pajak bumi dan bangunan PBB-P2 sebagai pajak daerah. http://www.pajak.go.id/content/pengalihan-pbb-perdesaan-dan perkotaan. Diakses pada tanggal 16Februari 2014.

Dispenda Kabupaten Sijunjung, 2016. Strategi Pemungutan Pajak Daerah.

Fuad. 2012. Payment online system pajak bumi dan bangunan. http://www.piramidasoft.com/. Diakses pada tanggal 28 November 2013. Kementrian Keuangan Republik Indonesia. 2012. Pelengkap buku pegangan penyelenggaraan pemerintah daerah dan pembangunan daerah: kebijakan hubungan keuangan pusat dan daerah. Direktorat jendral Perimbangan Keuangan Kementerian Keuangan Republik Indonesia. Jakarta.

Hartono, Sonny. 2012. Evaluasi PelaksanaanPengalihan Pajak Bumi Dan BangunanPerdesaan Dan Perkotaan (Pbb-P2)Sebagai Salah Satu Sumber Pendapataan Asli Daerah Kabupaten Sukoharjo. Skripsi. Universitas Sebelas Maret.

Mardiasmo. 2009. Perpajakan. Edisi XVI. Yogyakarta: Andi

Mardiasmo. 2011. Perpajakan Edisi Revisi2011. Yogyakarta:ANDI

Nadhia, dkk. 2013. Efektivitas Prosedur Penerimaan Pajak Bumi dan Bangunan(PBB) dari Pajak Pusat ke Pajak Daerah Pada Dinas Pendapatan Daerah Kota Palembang. JurnalAkuntansi STIE MDP

Peraturan Bersama Menteri Keuangan dan Menteri Dalam Negeri nomor: 213/pmk.07/2010, nomor: 58 tahun 2010 tentang Tahapan Persiapan Pengalihan Pajak Bumi dan Bangunan Perdesaan dan Perkotaan sebagai Pajak Daerah.

Rahman, A. 2011. Intensifikasi Pemungutan Pajak Bumi dan Bangunan Kecamatan Soerang Kota Pare-Pare. Skripsi. Universitas Hassanudin

Undang-Undang Nomor 28 Tahun 2009 Tentang Pajak Daerah dan RetribusiDaerah

Waluyo. 2011. Perpajakan Indonesia. Edisi 10. Salemba Empat. Jakarta 